Available online on 15.09.2020 at http://jddtonline.info
Open Access to Pharmaceutical and Medical Research
unrestricted non-commercial use, provided the original work is properly cited

Open Access

Research Article

\title{
In-house preparation, development and evaluation of herbal cosmetics face pack using various natural powders
}

\author{
Anilkumar V.1*, Kalyani R. ${ }^{2}$, Padmasri B. ${ }^{3}$, Prasanth D. ${ }^{4}$ \\ 1. Assistant Professor, Department of Pharmaceutical Technology, GIET School of Pharmacy, Rajahmundry, East Godavari, Andhra Pradesh, \\ India \\ 2.Assistant Professor, Department of Pharmaceutical Technology, Sri Venkateswara College of Pharmacy, Etcherla, Srikakulam, Andhra Pradesh, \\ India \\ 3. Assistant Professor, Department of Pharmaceutical Technology, Sri Venkateswara College of Pharmacy, Etcherla, Srikakulam, Andhra \\ Pradesh, India
}

4. Assistant Professor, Department of Pharmacology, Sri Venkateswara College of Pharmacy, Etcherla, Srikakulam, Andhra Prades h, India

\begin{abstract}
An eco- friendly product has been the primary agenda of 21 st century of the global scientists. Herbal cosmetics have growing demand in the global market. The aim of present work is to In-house preparation, development and evaluation of herbal cosmetics face pack using various natural powders for glowing skin by using natural Ingredients. The natural powders used are shade dried commercial turmeric, rice flour, gram flour, rose powder, tomato powder, orange peel powder. Sandalwood powder, milk powder, camphor powder were purchased form local market in the form of dried powder, all powdered natural ingredients were sieved using \#120 mesh, weighed accurately and mixed geometrically for uniform preparation and evaluated for parameters including macroscopical, Physiochemical, irritancy, antimicrobial tests along with stability studies. Thus, in this work we formulate herbal face pack by using easily available ingredients. After evaluation, we found good flow properties, free from skin irritation and maintained proper stability storage conditions. Results of this study scientifically verified that herbal face pack having enough potential to give efficient glowing effect on skin. The overall study is useful to substantiate product claims due to its benefits on the human being.
\end{abstract}

Keywords: herbal cosmetics, turmeric, Sandalwood powder, orange peel powder

Article Info: Received 10 July 2020; Review Completed 21 Aug 2020; Accepted 28 August 2020; Available online 15 September 2020

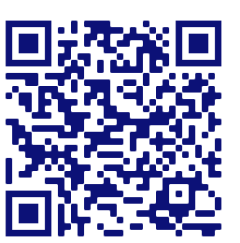

Cite this article as:

Anilkumar V, Kalyani R, Padmasri B, Prasanth D, In-house preparation, development and evaluation of herbal cosmetics face pack using various natural powders, Journal of Drug Delivery and Therapeutics. 2020; 10(5):159-164 http://dx.doi.org/10.22270/jddt.v10i5.4314

Anilkumar V., Assistant Professor, Department of Pharmaceutical Technology, GIET School of Pharmacy, Rajahmundry, East Godavari, Andhra Pradesh

\section{INTRODUCTION}

Now-a-days, the whole world there is return towards the use of herbal products and to adopt more natural way of life. People refer and prefer natural food, herbal medicines and natural curing practices for healthy life. There is much craze for the usage and great demand for the cosmetics. All this happened due to herbal products are having less side effects and health hazards and also much awareness is created amongst the consumers for health and better quality lives, which led towards more use of herbal drugs, herbal cosmetics. It is not simple to define the term "Cosmetic " because of its scope and application. The cosmetic is decorative to enhance the general appearance of face and other body parts to minimize the skin defects to a considerable extent. It is applied to maintain or improve the status of skin, it greatly helps men and women to look more impressive, beautiful and smart to a considerable extent.

Herbal cosmetics are the preparations, which represent cosmetics associated with bioactive ingredient or pharmaceutical. The use of Phytochemical from a variety of botanicals have dual functions I)They serve as cosmetics for the care of body and its parts and ii) The presence of botanical ingredients influence biological function of skin and provide nutrients necessary for the healthy skin ${ }^{1}$.The herbal cosmetics formulation is a sophistical and sensitive technological profile because it retains the bioactivity of the 
botanicals during excessive processing and asertains their availability after application on skin.It is desirable that manufacturers should ensure the quality of products through systematic testing at their level.

In ancient times, women were very conscious about their beauty and took special care of their specific skin types. Even today people especially in rural areas, and hilly regions go for the natural remedies like plants extracts for various cosmetics purposes like Orange peel, Rose powder, Tomato powder, Aloevera, Turmeric etc. Herbal cosmetics are the products which are used to purify and beautify the skin. The main advantage of using herbal products is that it is pure and does not have any side effects on the human body. ${ }^{2}$ According to Ayurveda, skin problems are normally due to impurities in blood. The herbal paste which is applied on face to treat acne, pimple, scars, marks and pigments are known as" Mukha lepa" in Ayurveda. This process of smearing this herbal mix on face is known as "Mukha lepana" .This beauty therapy is now popularly termed as facial. $^{3}$

Nowadays different types of packs are available separately for the oily, normal and dry skin. Face packs are used to increase the fairness and smoothness of the skin. It reduces wrinkles, Pimples, acne and dark circles of the skin. Face packs which are recommended for oily skin prone to acne, black heads usually control the rate of sebum discharge from sebaceous glands and fight the harmful bacteria present inside acne lesion. Herbal face packs are being used on a large scale, due to the various benefits of them over chemical based packs. They are non-toxic, non-allergic and non-habit forming. They are natural in every aspect, having large shelf lives. They have no need preservatives and they can be easily formulated and stored over a larger span of time. ${ }^{2}$

\section{Benefits of Applying Face pack: 4,5}

1. Nourishes the skin, fruit face packs supply essential nutrients to the skin.

2. Face pack which is recommended for acne, pimple, black heads, usually control the over discharge of sebum from sebaceous glands and remove the harmful bacteria inside acne lesion.

3. The scars and marks of skin can be reduced by adding fine powder of sandal, rose petals and orange lentils with acne face pack.

4. Face packs usually remove dead cells of the skin.

5. These face packs and masks provide soothing and relaxing effects on the skin.

6. They help to restore the lost shine and glow of skin in short span of time.

7. Regular use of natural face packs brings a glow to the skin, improve skin texture and complexion.

8. The harmful effects of pollution and harsh elements can be effectively combated with judicial use of face pack.

9. They help to prevent premature aging of the skin.

10. Formulation of wrinkles, fine lines and sagging of skin can be effectively controlled by using natural face packs.

11. Natural face packs make the skin look young and healthy.

Precautions to be taken while applying for face and body: 4,5
1. Select the face pack according to your skin type. Take the opinion of a natural therapist or concerned skin expert before applying a face pack.

2. The face pack should not be left on the face more than 15 to $20 \mathrm{~min}$. Keeping for very long time may result in the formation of wrinkles, sagging skin and enlargement of open pores.

\section{Apply face pack once in a week.}

4. Don't try to peel or scratch the dried face packs this may harm underlying skin. Spray water (which is at room temperature) on the face before removing dried face pack. After removing the mask, roll an ice cubes on facial skin. This helps to close open pores and tightens skin. It also tones and soothens the skin.

5. Do not Scrub face vigorously. This may result in the eruption of pimple and dark spots.

\section{Stay away from heat when you have applied a face pack.}

7. Avoid applying face pack near" eye zone". The skin around the eye is very delicate. The process of removing face pack may damage the skin around eyes.

\section{MATERIAL AND METHODS:}

The all natural materials used in the present study i .e Sandal powder, Milk Powder, Camphor were Purchased from local market in the dried Powder form. Remaining natural ingredient powders were prepared by shade drying and Grinded to make fine powder by using Size reduction mill and Grinder such as Turmeric, Rice flour, Gram flour, Rose powder, Potato powder, Tomatoe powder, Orange peel powder.

1. Turmeric: Turmeric has been used in the formulation due to antiseptic action. It cures the skin diseases occurring due to blood impurities. It is a very good anti-inflammatory and antiallergenic agent. The phyto constituents, mainly terpenoids present in it helps to lighten the skin tone. Turmeric delays the signs of aging like wrinkles, improves skin elasticity. It cures pigmentation, uneven skin tone and dull skin. ${ }^{6}$

2. Sandalwood: Sandal wood has an anti-tanning and antiaging property. Sandal woods protect the skin against the impact of environmental pollution and keep the skin cool, fair and healthy. Sandal wood is helpful ayurevedic herb with antimicrobial property is used for healing various skin problems and remove scars. ${ }^{7}$ Sandle wood may have different effects on the skin. Constituents of Sandalwood wood may restore and rejuvenate wrinkles skin by several activities and antioxidants, anti-inflammatory, cell regulatory properties. Sandal wood with potential to develop dermatological treatment and skin care products.

3. Rice flour: Rice flour can be applied to cure some forms of skin ailments. In Indian subcontinent, rice water is duly prescribed by Ayurevedic practitioners as in undigested form. It aids the growth of useful bacteria for normal bowel movements, an effective ointment to cool off inflamed skin surface. Rice water used has rich content of Thiamine. ${ }^{8}$

4. Gram flour: The high content of Zinc in gram flour will help to fight infections that cause acne. It removes dead skin, astringent and protective. Gram flour widely used house remedies for facial and marriage haldi functions also. ${ }^{9}$

5. Rose petals powder: Rose petals powder is rich with the antibacterial properties, all with the positive effects of vitamins $\mathrm{K}, \mathrm{C}$ and B. It also has good amount of antioxidants. ${ }^{9}$ 
6. Orange peel powder: It cures blackheads, cell build up around the pores brightness your face, dark circles, dry skin, wrinkles, aging, prevent acne. Orange peel can be used for facial cosmetics. Orange as a folk medicine. And it is a good source of Vit C, B, Flavonoids, terpenes as per traditional Chinese symbol good luck and prosperity. Antibacterial, Antifungal, Larvicidial activity. ${ }^{10}$

7. Tomato Powder: Tomato have large amount of antioxidant and vitamin C. Use of tomatoes for face whitening as they acts as a natural bleaching agent, pimple and acne reduction, antiageing, reduces oiliness, blackheads and also help wake up the dullest of skin. tomato may sooth skin inflammation, stimulate collagen production and help remove dead skin cells. Tomatoes also helps to shrink large pores and brightens up skin complexion, it contains salicylic sour a common ingredients in acne products. It cleanness and exfoliates to remove dead skin cells that can clog pores and white heads or black heads.

8. Potatoes Powder: Potatoes Contains an enzyme called " Catecholase" which helps to brighten skin and get rid of dark spots. Potato juice to lessen the appearance of dark circles. Antiaging and can gently exfoliate skin. Potatoes have essential nutrients, including Potassium and vitamins. Potato powder has shown antioxidants, antimicrobial, wound healing. Management and best pharmaceutical ingredient.

9. Milk powder: It is very beneficial for skin, as it provides nourishment for dry, rough skin for the longer duration. Milk cream either in the form of powdered raw milk or milk as such provides a brilliant shine to skin. This is beneficial in hydrating the face deeply and makes skin youthful, lustrous and flawless.It bleaches the skin to remove dark spots, Pigmentation, acne etc... This pack also removes blackheads, white heads and other skin imperfections naturally. ${ }^{11}$

10.Camphor: Camphor is obtained from the bark of the tree Cinnamonu camphora on the skin it acts as a counter irritant, camphor can help in getting rid of rashes and redness when used as topical itch relieving gels, camphor helps in inflammation and which is widely used in many lotions, liniments and ointments.

\section{Preparation of Natural Powders:}

1. Preparation of Turmeric Powder: Turmeric rhizome are collected and dried under sunlight. Later turmeric rhizomes are grind to make a fine powder and sieved.

2. Preparation of Rice flour: Required quantity of rice taken and soaked in water for at least $2 \mathrm{hrs}$. Drain water completely and rinse again and the spread the raw rice on a soft cloth and allow it to dry for 30-45 mins. It will be slightly moist only and few rice will stick to your hands when touch. This is the perfect stage then transfers this to a mixer or grinder. Grind to a fine powder transfer to sieve. Sieve it well until get a coarse mixture powder. ${ }^{12}$

3. Preparation of Gram flour: Required quantity of chickpeas dried under sunlight for easily grinding at least one day. After completion of drying transfer to a mixer or grinder. Grind to a fine powder. Transfer to Sieve it well until get a coarse mixture powder.

4. Preparation of Rose petals Powder: Collect fresh rose petals wash with water for 2-3 times. Dry these petals in shade for one to two hours and then churn them with sugar in mixer. This will make a paste put this paste in a plate for drying it takes about 6-7hrs for drying. Make a powder.

5. Preparation of Orange peels Powder: collect fresh sweet oranges. The fruits were washed, weighed, peeled by using knife and were cut into small pieces (10 to $20 \mathrm{~mm}$ ), after that they were washed using hot water at $90^{\circ} \mathrm{c}$ for 5 min. After that peel surface moisture was removed, then it was followed by solar tunnel drying. After dried, peel were grinded mixer jar or coffee grinder to make a fine powder. ${ }^{13}$

6. Preparation of Tomato Powder: Tomato powder prepare in two methods i)Sun dried method, ii) Hot air oven method. Here we follows Sun dried method, The tomatoes were stored, washed, sliced. Sliced tomatoes directly dried in sunlight. Sun dried tomatoes slices are grind them in a mixer jar or coffee grinder to make a fine powder and Store in an air tight container.

7. Preparation of Potato Powder: The Potatoes were stored, washed to remove adhering dirt, peeled, sliced, and blanched in boiling water for $4 \mathrm{~min}$, dipped in $10 \%$ salt solution and $0.05 \%$ Potassium metabisulphate for $15 \mathrm{~min}$ to avoid browning, dried in hot air oven at $60^{\circ} \mathrm{c}$ for $8-9 \mathrm{hrs}$. The dried slices of potatoes were ground to fine powder and sieved. ${ }^{14}$

Method of Preparation of Face Pack: Different formulations were prepared with different concentrations of all ingredients named as FPP. The accurate quantity of ingredients were weighed and ground into fine powder by using sieve \#120. Then all the ingredients were mixed geometrically by serial dilution method for uniform mixing. Then the prepared face pack was packed into a self-sealable polyethylene bag and Labelled. ${ }^{15,16}$

Table 1: Formulation table for herbal face pack

\begin{tabular}{|c|c|c|c|}
\hline S.No & Ingredients & Amount in gms & Activity \\
\hline 1. & Turmeric powder & 15 & Anti-aging agent \\
\hline 2. & Sandalwood powder & 10 & Anti-tanning agent \\
\hline 3. & Rice flour & 15 & Vitamin B \\
\hline 4. & Gram flour & 20 & Astringent \\
\hline 5. & Rose powder & 10 & Skin tonner \\
\hline 6. & Orange peel powder & 10 & Antioxidant \\
\hline 7. & Tomato powder & 05 & Anti-aging \\
\hline 8. & Potato powder & 05 & Hydration \\
\hline 9. & Milk powder & 05 & Counter irritant \\
\hline 10. & Camphor powder & 05 & \\
\hline & Total in grams & $100 \mathrm{~g}$ & \\
\hline
\end{tabular}




\section{Evaluation tests:}

Organoleptic Properties: All formulations were evaluated for Physical Parameters like color, odor, Consistency and feel.

Particle Size: Control of Size and the size range of Particles is of a profound importance in Pharmacy Clinically, the particle size of a drug can affect its release from dosage forms. The successful formulation of Biphasic liquid dosage form such as emulsion, suspension and Solid dosage form such as tablets, both dosage forms Physical stability and Pharmacological response depends on the particle size.

Sieving method: This method is the simplest and most widely used method of determining particles size and size distribution. In this method utilizes a series of standard sieves calibrated by the national bureau of standards. According to the method of USP a definite mass of sample is placed on the proper sieve in a mechanical shaker. The powder is shaken for a definite period of time and the material that passes through one sieve and fine itsieve is collected, weighed and then calculated the particle size.

\section{Evaluation of flow properties of face pack powder: ${ }^{17}$}

Angle of repose: ${ }^{17}$ The friction forces in a loose powder can be measured by the angle of repose. It is an indicative of the flow properties of the powder. It is defined as maximum angle possible between the surface of the pile of powder and the horizontal plane.

The powder mixture was allowed to flow through the funnel fixed to a stand at definite height (h).The angle of response was then calculated by measuring the height and radius of the heap of powder formed. Care was taken to see that the powder particles slip and roll over each other through the sides of the funnel. Relationship between angle of repose and powder flow property.

$$
\operatorname{Tan} \theta=\mathrm{h} / \mathrm{r}
$$

Where, $\theta=$ angle of repose $\mathrm{h}=$ height of the cone $\mathrm{r}=$ radius of the base

Bulk density $\left(D_{b}\right): 17$ is the ratio of total mass of powder to the bulk volume of powder. It was measured by pouring the weight powder (Passed through standard sieve \#20) into a measuring cylinder and initial weight was noted. This initial volume is called the bulk volume. From this the bulk density is calculated according to the formula mentioned below it is expressed in $\mathrm{g} / \mathrm{ml}$ and is given by,

$$
\mathrm{D}_{\mathrm{b}}=\mathrm{M} / \mathrm{V}_{\mathrm{b}}
$$

where, $M=$ the mass of powder $V_{b}=$ the bulk Volume of the powder

Tapped density $\left(D_{t}\right):^{17}$ It is the ratio of total mass of the powder to the tapped volume of the powder. Volume was measured by tapping for 750 times and the tapped volume was noted if the difference between these two volumes is less than 20\%. If it more than 2\%, tapping is continued 1250 times and tapped volume was noted. Tapping was continued until the differences between successive volumes is less than $2 \%$ ( in a bulk density apparatus) it is expressed in $\mathrm{g} / \mathrm{ml}$ and is given by

$$
D_{t}=M / V_{t}
$$

where, $M=$ the mass of the powder $V_{t}=$ the tapped volume of powder

Carr's index or \% Compressibility: 17 It indicates powder flow properties. It is expressed in percentage and is give by,

$$
I=\frac{D_{t}-D_{b}}{D_{t}} \times 100
$$

where, $D_{t}=$ the tapped density of the powder

$\mathrm{D}_{\mathrm{b}}=$ the bulk density of the powder

Hausner's ratio: ${ }^{17}$ Hausner ratio is an indirect index of ease of powder flow. It is calculated by the following formula

Hausner's ratio $=D_{t} / D_{b}$

Ash content: 18 Determining the ash content of a any material is part of proximate analysis for nutritional evaluation and it is an important quality attribute for some food ingredients also ashing is the first step in the preparation of a sample of specific elemental analysis. This laboratory exercise uses the dry ashing technique with a muffle furnace to determine the ash content. Two major types of ashing procedures are commonly used Dry ashing and Wet ashing.

Dry ashing is heating material at elevated temperature (500$600{ }^{\circ} \mathrm{c}$ ) in a muffle furnace. Water and volatiles will evaporate and organic matter will burn in the presence of oxygen and convert to carbon dioxide and oxides of Nitrogen.

Wet ashing is based on oxidizing organic matter using acids and oxidizing agents or their combination. Minerals are thus solubilized without oxidation. The ash content can be expressed on a wet basis or a dry basis.

\section{Procedure:}

1. Accurately weight $2 \mathrm{gm}$ of sample into the crucible and record weight on the spread sheet.

\section{Place crucible in muffle furnace oven at $550^{\circ} \mathrm{c}$ for $24 \mathrm{hrs}$.}

3. Turn off the muffle furnace and allow it to cool(might take a few hours)

4. Remove crucible from the muffle furnace and placed into a desiccator to cool. Weigh the ashed sample and record weight of crucible plus ashed sample.

Weight of ash= (weight of crucible and ash) - weight of crucible

$$
\% A s h=(\text { weight of ash } / \text { original sample weight }) \times 100
$$

Determination of $\mathbf{p H}$ of Powder: ${ }^{19} \mathrm{pH}$ is not a characteristics of powders, but $\mathrm{pH}$ of powdered materials is specified as a value at a specific percentage of solids.

Procedure: Weigh the $5 \mathrm{gm}$ of the test sample and transfer into a flask. Add a $100 \mathrm{ml}$ of distilled water, stopper the flask and shade for a minute. Allow it to settle for one hour. Calibrate the $\mathrm{pH}$ meter and transfer an appropriate amount of the clear aqueous solution from the flask into the beaker. Measure the $\mathrm{pH}$ value and report.

Determination of Moisture content: Moisture Content is important for the plant drugs because insufficient drying may lead to possible enzymatic deterioration of active principles. Weigh accurately about 3 gms of powder drug was taken in Petri dish and placed in Hot air oven and measure the weight after $30 \mathrm{~min}$ upto standard weight. ${ }^{17}$

Washability: ${ }^{20}$ Formulation was applied on the skin and then ease and extent of washing with water were checked manually.

Irritancy test:21 Mark an area(1Sq $\mathrm{cm})$ on the left hand dorsal surface. Definite quantities of prepared face pack were applied to the specified area and time was noted. Irritancy and edema was checked and reported. 
Antimicrobial evaluation:20,22 Formulation was tested for antibacterial activity against test organisms namely Staphylococcus aureus and Propioni bacterium acnes were obtained from the Pharmaceutical Biotechnology lab. In this method, nutrient agar plates and reinforced clostridial agar (RCA) were seeded with 100 micro liter standardized bacterial suspension. After optimization of dose, $200 \mathrm{mg}$ of formulation was mixed with distilled water and poured into the wells. Standard conditions and antibacterial activity was evaluated by measuring the diameter of Zones of inhibition (mm) including cupsize. The experiments were repeated three times.

Determination of microbial load: The prepared formulations were evaluated for total viable count, presence of gram negative pathogens such as E. coli, Pseudomonas done at Pharmaceutical Biotechnology lab.

Stability Studies:21 Stability testing of prepared formulation was conducted for formulations by storing at different temperature conditions for the period of one month. The packed glass vials of formulation stored at different temperature as room temperature, $35^{\circ} \mathrm{C}$ and $40^{\circ} \mathrm{C}$ were evaluated for Physical parameters like color, odour, $\mathrm{pH}$, Texture and Smoothness.

\section{RESULTS AND DISCUSSION:}

The results of evaluation are shown in table for organoleptic and general powder. The Study of nature, Color, odour, taste, texture, ash content, Moisture Content and $\mathrm{pH}$ of dried powders of combined form under investigation provided the important features of organoleptic and Physiochemical Evaluation. The presence of color is slight yellowish pink. Odour is slight, texture is fine. The presence of ash in the dried powder of combined form was evaluated for total ash yield and it was found 4.1. Moisture content value was found to be $3 \%$. The moisture content values observation clearly indicated that the powder of combined form was hygroscopic in nature. The dried powder of formulation was determined by preparing $1 \%$ dispersion of powder form in distilled water and measuring the $\mathrm{pH}$ with $\mathrm{pH}$ meter. The $\mathrm{pH}$ of $1 \%$ dispersion of powder was obtained 7.1 which indicates that the powder combined form were slightly alkaline in nature. Dried powder of combined form was evaluated and the results are, for particle size22.5,angle of repose $15 \pm 1.8$, Bulk density $1.05 \mathrm{~g} / \mathrm{cc}$, tapped density 1.38 $\mathrm{g} / \mathrm{cc}$, Carr's index 23.91,Hausner ratio 1.31 respectively. The Powder have good flow properties which is suitable for a face pack and it is easily washable with water, the formulation shows absence of irritancy, redness and swell during irritancy studies table 2 .And its easily washable with water. Antimicrobial evaluation was performed two organasms staphylococcus aureus acne, Propioni bacterium Zone of inhibition was found formulation in table 3 and microbial load in table 4 . The results of stability studies of the formulation show No Change in color, odour, texture and smoothness at mentioned conditions of stability except $\mathrm{pH}$. The stability studies showed a slight change in $\mathrm{pH}$ of formulations at $40^{\circ} \mathrm{C}$ table 5 .

Table: 2. Evaluation table of herbal face pack

\begin{tabular}{|c|c|c|}
\hline S.No & Evaluation Parameters & Observation \\
\hline A & \multicolumn{2}{|c|}{ Organoleptic evaluation } \\
\hline 1. & $\begin{array}{c}\text { Nature } \\
\text { (appearance) }\end{array}$ & $\begin{array}{c}\text { Powder } \\
\text { (free flowing) }\end{array}$ \\
\hline 2. & Color & Slight Yellowish pink \\
\hline 3. & Odour & Slight \\
\hline 4. & Texture & Fine \\
\hline B & \multicolumn{2}{|c|}{ Physiochemical evaluation } \\
\hline 1. & Total ash & 4.1 \\
\hline 2. & Moisture content & $3 \%$ \\
\hline 3. & 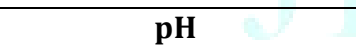 & 7.11 \\
\hline $\mathrm{C}$ & \multicolumn{2}{|c|}{ General Powder characteristics } \\
\hline 1. & Particle size & 22.5 \\
\hline 2. & Angle of repose & $15 \pm 1.8$ \\
\hline 3. & Bulk density & 1.05 \\
\hline 4. & Tapped density & 1.38 \\
\hline 5. & Carr's index & 23.91 \\
\hline 6. & Hauser's ratio & 1.31 \\
\hline 7. & Grittiness & No gritty particles \\
\hline 8. & Washability & Easily washable \\
\hline 9. & Microscopical features & Sclrenchyma, liginified fibres \\
\hline $\mathrm{D}$ & \multicolumn{2}{|c|}{ Irritancy test } \\
\hline 1. & Irritation & No \\
\hline 2. & Redness & No \\
\hline 3. & Swelling & No \\
\hline
\end{tabular}


Table 3: Antimicrobial evaluation

\begin{tabular}{|c|c|c|c|c|}
\hline \multicolumn{3}{|c|}{ Antimicrobial evaluation } \\
\hline S.No & Staphylococcus aureus acne & \multicolumn{2}{c|}{ Propioni bacterium } \\
\hline 1. & Clindamycin & 12 & & 13 \\
\hline 2. & Herbal Face Pack & 08 & & 08 \\
\hline
\end{tabular}

Table 4: Determination of Microbial load:

\begin{tabular}{|c|c|c|}
\hline S.No & Test & Observation \\
\hline 1. & Total viable count (CFU/g) & 918 \\
\hline 2. & $\begin{array}{c}\text { Gram negative pathogens (CFU/g); E. coli, } \\
\text { Pseudomonas }\end{array}$ & Absent \\
\hline
\end{tabular}

Table: 5 Stability studies

\begin{tabular}{|c|c|c|c|}
\hline S.No & Parameters & Room temperature & At 40C \\
\hline 1. & Color & No Change & No Change \\
\hline 2. & Odour & No Change & 7.14 \\
\hline 3. & pH & 7.1 & Fine \\
\hline 4. & Texture & Fine & Smooth \\
\hline 5. & Smoothness & Smooth \\
\hline
\end{tabular}

\section{CONCLUSION:}

Natural and home remedies are widely acceptable in the belief that they are safer with fewer side effects than the synthetic materials. Herbal face packs are used to stimulate blood circulation, rejuvenate the muscle and help to maintain the elasticity of the skin and remove dirt from skin pores. Herbal cosmetics advantages are nontoxic nature, reduce the allergic reaction. This face pack is beneficial, economical, and passed all evaluation parameters. It has been revealed that herbal face pack having enough potential to give efficient glowing effect on skin. The overall study is useful to substantiate product claims due to its useful benefits on the human beings.

\section{REFERENCES:}

1. Kapoor VP, Herbal Cosmetics for skin and Hair care Indian Journal of Natural Products and Resources, Aug 2005; 4:306-314.

2. Saxena R, Pal Y, Pranaywal In-House Preparation and standardization of Herbal face pack.the open Dermatology Journal. 2017; 11:72-80.

3. Yadav N And Yadav R, Preparation and evaluation of Herbal face pack International Journal of Recent Scientific Research 2015; 6(6):4334-4337.

4. Pathashala. MHRD Govt.of India.An MHRD Project under its National mission on education through ICT(NME-ICT).

5. Saraf S, Saraf S. Cosmetics a Practical manual, Pharma med Press, 2nd edition, 2005; 126-129.

6. Mieloch M, Witulska M, Evaluation of skin colouring properties of Curcuma longa extract.Int.J Pharm Sci 2014; 76(4):374-8.

7. Bhat KV, Balasundaran M, Balagopalan M, Identification of Santalum album and osyrislan cedata through morphological and biochemical characteristics and molecular markers to check adulteration (Final Report of the project KFRI 509/06)

8. Umadevi M, Puspha R, Sampath kumar KP, Bhowmik D. Ricetraditional medicinal plant in India. Journal of Pharmacognosy and Phytochemistry 2012; 1(1):6-12.
9. Bhagwat S, Aglawe A, Gayle U, Mindhe SA, Rane SG, Formulation and evaluation of Herbal Face pack Int J Pharm Biol Sci. 2018; 8:49-52.

10. Parle M, Chaturvedi D. Orange : Range of Benefits IRJP 2013; 3(7):59-63.

11. Sinha NK. Beauty and skin Benefits of milk powder Milk powder Homemade Facial mask recipes available from http://nutankumarisinha.

12. http://www.sharmispassion.com/how-to-make-rice-flour-athomemade

13. Sankalpa KB, Ramachadra CT, Dinesha BL, Nidonl UK, Effect of different drying and grinding methods on biochemical properties of sweet orange peel powder. Asian J.Dairy and food Red. 2017; 36(3):260-263.

14. Kaur A, kochhar A, Pradad PS, Development and Nutritional evaluation of products using potato flour for malnourished children. Ijhsr.June 2015; (5):554-560.

15. Farheen B, Mohammed I. Design and development of unani face pack for skin care.European J Pharm Med Red 2016; 3(2):627632.

16. Somwanshi SB, Kudale KS, Dolas RT, Kotade KB, Formulation and evaluation of cosmetic herbal face pack for glowing skin. Int.J.Red.Ayurveda Pharm.2017; 8(3):199-203.

17. Laxmi M, Vijayalakshmi S, Development and evaluation of Herbal face pack using various plant powders Indo Am.J.P.Sci, 2017; 4(09).

18. Ismail B.P. Ash content Determination. In:Food Analysis Laboratory Manual. Food Science Text series. Springer, Cham 21 June 2017; 978-3-319-44125-2.

19. http://digitalfire.com/test/phpW.

20. Himaja N, Ashok kumar A, Bhart kumar B, Preparation and evaluation of poly herbal fruit face mask Quest Journals.Journal of Research in Pharmaceutical Science 2015; 2(11):07-13.

21. Indian Standard, Face pack-Specification, 2002; IS 15153.

22. Valgas C, Machado de sonza S, Smania EFA, Smania A, Jr.Screening methods to determine antibacterial activity of natural products. Braz J microbial, 2007; 38:369-380. 